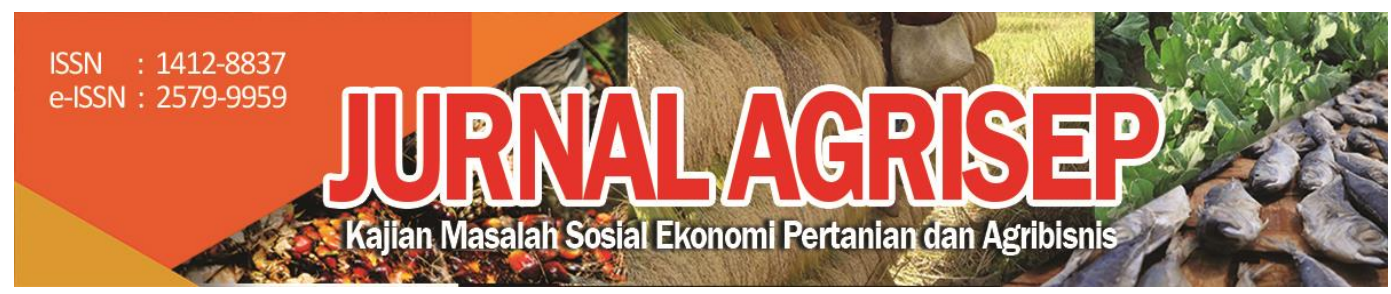

DOI: 10.31186/jagrisep.19.2.275-288

\title{
JIWA KEWIRAUSAHAAN PELAKU AGROINDUSTRI KOPI DI KOTA BUKITTINGGI
}

\author{
Entrepreneurial Spirit Of Coffee Agro-Industry Entrepreneur In \\ Bukittinggi

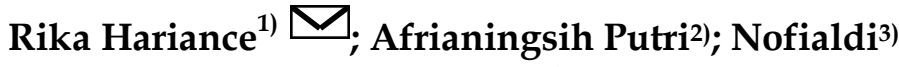

1),2),3) Agribusiness Study Program, Faculty of Agriculture, Andalas University Email: rikahariance@gmail.com
\end{abstract}

\begin{abstract}
The growing number of coffee agro-industries, the increase of consumers' interest in coffee, and the challenges of industrial revolution 4.0, are driving demand for improving coffee agro-industry business. It encourages entrepreneurs to develop their entreprenuerial skills. This study aims to analyze the entrepreneurial spirit of the coffee agro-industry's entrepreneur in Bukittinggi city in encountering industrial revolution 4.0. Bukittingi was selected as the study area due to leading tourist destinations in West Sumatera and its coffee agro-industry known as "Rang Bukik Apik". This research used survey method. Thirty coffee agro-industry entreprenuers were selected by simple random sampling technique. The research found that of 15 indicators assessed, the average of all indicator's summary is $82.49 \%$. Coffee agro-industry actor in Bukittinggi are people who are willing to take all risks, always think about goals, confident, like a challenges, like to take full outhority over themselves, optimistic, happy to immerse themselves into a work, statisfied with their product, have a high standar for the quality of work, considers of that personal and professional development is more important than senses of calm, money and prestige, likes to work hard and can combine the power of reason and intusion. To conclude, coffee agro-industry's entrepreneurs are characterized by their high entrepreneurial spirit and capability to develop their business through product innovation and manufacturing of value-added products. At the same time, these charactiristics would be able to support entrepreneurs in facing industrial revolution era 4.0 challenges.
\end{abstract}

Keywords: Agroindustry, Coffee, Entrepreneurial spirit 


\begin{abstract}
ABSTRAK
Semakin banyaknya agroindustri kopi yang bermunculan dan semakin meningkatnya minat konsumen terhadap minuman kopi, serta tantangan revolusi industri 4.0, menuntut para pelaku agroindustri kopi di Kota Bukittinggi untuk dapat mengembangkan usahanya lebih baik lagi. Salah satunya dilakukan melalui kemampuan kewirausahaannya. Penelitian ini dilakukan untuk menganalisis jiwa kewirausahaan yang dimiliki oleh pelaku agroindustri kopi di Kota bukittinggi dalam mengahadapi era revolusi industri 4.0. Pemilihan Kota Bukittingi dilakukan karena kota ini merupakan daerah tujuan wisata unggulan Sumatera Barat yang memiliki agroindustri kopi yang terkenal yaitu Kopi "Rang Bukik Apik". Penelitian yang dilakukan dengan metode survei kepada 30 pelaku agroindustri kopi yang dipilih secara simple random sampling menghasilkan bahwa dari 15 indikator yang dinilai, hasil penjumlahan rata-rata untuk keseluruhan indikator adalah 82,49\%. Ini menunjukkan secara keseluruhan pelaku agroindustri kopi di Kota Bukittinggi memiliki jiwa kewirausahaan yang tinggi. Pelaku agroindustri kopi di Kota Bukittinggi adalah orang yang bersedia menempuh segala resiko, selalu memikirkan tujuan, percaya diri, menyukai tantangan, menyukai kewenangan penuh atas dirinya, optimis, senang membenamkan diri dalam pekerjaannya, puas dengan apa yang telah dihasilkannya, memiliki standar yang tinggi bagi kualitas pekerjaannya, beranggapan bahwa mengembangkan diri dan profesi lebih diperlukan dari pada rasa tenang, uang dan gengsi. Mereka juga suka bekerja keras serta bisa menggabungkan daya nalar dan intusinya. Dengan demikian dapat disimpulkan bahwa setiap pelaku usaha kopi di Kota Bukittinggi memiliki karakteristik jiwa kewirausahaan yang tinggi dan kemampuan untuk dapat terus mengembangkan diri melalui inovasi serta meningkatkan penciptaan nilai tambah produk. Pada saat yang sama karakteristik ini akan dapat mendukung pengusaha dalam menghadapi tantangan revolusi industri 4.0.
\end{abstract}

Kata Kunci : Agroindustri, Jiwa Kewirausahaan Kopi.

\title{
PENDAHULUAN
}

Menghadapi era globalisasi untuk mampu bersaing, maka seorang wirausaha yang bergerak di sektor pertanian diharapkan memiliki kemampuan daya saing yang kuat agar mampu bertahan menghadapi tantangan global yang selalu bergerak dinamis. Sejalan dengan itu, Daryanto (2009) berpendapat bahwa pemerintah mendukung penuh para pelaku pembangunan pertanian, melalui pembangunan ekonomi yang didasarkan pada potensi yang dimiliki, kondisi kemajuan yang telah dicapai, serta tantangan yang dihadapi dan prospek pengembangannya (kedepan). Dengan demikian, maka Soedjais (2003) menyebutkan bahwa perusahaan yang memiliki keunggulan bersaing akan dapat bertahan dan terus berkembang dalam persaingan global. Sedangkan sisanya akan menjadi "pedagang pinggiran" dan menjadi marginal dalam tata perekonomian global. Kemudian, globalisasi juga mendorong korporasi untuk 
saling bersaing mati-matian, tetapi juga bekerjasama mati-matian, baik untuk mempertahankan hidup, mengembangkan bisnis, maupun untuk mencegah persaingan yang berujung saling membunuh.

Upaya yang tepat untuk menghadapi persaingan menurut Joseph Schumpter adalah dengan menciptakan inovasi, dengan demikian maka perekonomian akan tumbuh. Agar perusahaan dapat menciptakan keunggulan dan mampu bersaing secara kompetitif, maka agen utama yang sangat dibutuhkan adalah pengusaha itu sendiri (Tuluce, 2015). Oleh karena itu, seorang wirausaha adalah aktor terpenting dalam sebuah perusahaan untuk menciptakan inovasi. Tindakan yang dilakukannya akan menentukan perkembangan perusahaan saat ini dan dimasa depan. Selain itu Nunes, (2016) menyatakan bahwa inovasi yang dimiliki oleh pengusaha merupakan hal yang penting dalam memacu pertumbuhan ekonomi sebuah negara. Keberadaan pengusaha sangat penting untuk meningkatkan pertumbuhan ekonomi, karena dengan adanya inovasi yang diciptakan akan membuka lapangan pekerjaan baru dan meningkatkan jumlah produksi dan konsumsi yang akan memicu peningkatan pertumbuhan ekonomi.

Dalam hal ini, sejalan dengan pendapat Kashmir (2010) bahwa daya inovasi (juga) merupakan kemampuan yang harus dimiliki oleh seorang wirausaha. Seperti yang dituliskannya dalam pengertian kewirausahaan yaitu "sesuatu kemampuan kreatif dan inovatif (create new and different) yang dijadikan kiat, dasar, sumber daya, proses dan perjuangan untuk menciptakan nilai tambah barang dan jasa yang dilakukan dengan keberanian untuk menghadapi risiko". Dengan demikian kemampuan kewirausahaan seorang pengusaha, dapat menentukan kemampuannya dalam menghadapi persaingan global.

Kemudian dalam tulisannya, Hassim (2016) menjelaskan tentang era persaingan revolusi industri 4.0 yang merupakan era industri generasi keempat, era dimana ketika disruptif tekhnologi datang dengan cepat yang kemudian dapat mengancam perusahaan. Pada era ini, perusahaan raksasa dapat mati jika tidak mampu merespon perkembangan tekhnologi tersebut. Maka, ukuran perusahaan tidak-lah menjadi penting, namun kelincahan perusahaanlah yang dapat menjadi sebab utama keberhasilan perusahaan menghadapinya. Dengan demikian, kelincahan perusahaan tentu juga dipengaruhi oleh kelincahan pengusahanya, maka kemampuan kewirausahaan yang dibuktikan dalam jiwa kewirausahaan yang dimiliki oleh pengusahanya menjadi penting bagi perkembangan perusahaan dalam revolusi industri 4.0

Bukittinggi adalah kota wisata Sumatera Barat yang sangat digemari oleh wisatawan lokal, nasional, maupun internasional. Dengan begitu pembangunan ekonomi wilayah Kota Bukittinggi tumbuh dan berkembang dengan mengikuti kebutuhan akan kota wisata. Begitu juga dengan perkembangan industri kecil dan menengahnya, berdasarkan kepada data 
potensi industri kecil dan menengah Sumatera Barat, pada tahun 2015 terjadi peningkatan jumlah semua jenis industri kecil dan menengah di Kota Bukittinggi. Industri yang mengalami peningkatan paling besar adalah industri yang mengolah pakaian jadi dan tekstil, kerupuk dan sejenisnya, kue-kue basah, bordir dan sulaman, dan pengolahan kopi. Industri pengolahan kopi atau dapat kita sebut juga dengan agroindustri karena berbasis pada bahan baku yang berasal dari pertanian (agro) mengalami peningkatan jumlah sebanyak 12 unit menjadi 72 unit pada tahun 2015 dan hingga penelitian ini dilaksanakan. Hal ini dapat juga berdampak pada semakin ketatnya persaingan pada bisnis ini. Terlebih lagi perkembangan zaman yang semakin maju, membuat gaya hidup konsumen lebih selektif dalam membeli suatu produk dan menginginkan adanya variasi pada olahan kopi.

Untuk dapat bersaing dengan produk olahan yang sama pada pasar lokal maupun internasional, pengusaha agroindustri kopi di Kota Bukittingi mestilah memiliki kemampuan kewirausahaan yang baik. Karena persaingan global menuntut seorang pengusaha dapat menciptakan produk yang bermutu, kuantitas yang cukup dan mampu memasarkannya dengan baik agar tidak hanya menjadi "pedagang pinggiran" dan terkalahkan oleh kompetisi global.

Artikel dengan judul Jiwa Kewirausahaan Pelaku Agroindustri Kopi di Kota Bukitttinggi ini memiliki tujuan untuk menganalisis jiwa kewirausahaan yang dimiliki oleh pelaku agroindustri kopi di Kota Bukittinggi. Ini penting dilakukan karena berdasarkan data ekspor-impor dapat diketahui bahwa, produksi kopi Indonesia sebesar 50\%-80\% dari total produksi adalah untuk ekspor. Kopi di jual dalam bentuk green bean (biji kopi) dan hanya sebanyak $0,5 \%$-nya saja dalam bentuk olahan. Negara tujuan ekspor nya adalah beberapa negara di Eropa, Amerika bahkan sebagian Asia. Jumlah ekspor biji kopi Indonesia menurut Direktorat Jenderal Perkebunan (2017) dari tahun 1975 hingga 2016 terus mengalami peningkatan dari 128 ribu ton hingga 534 ribu ton pada tahun 2016.

Namun, peningkatan jumlah penduduk yang juga diiringi oleh peningkatan pendapatannya, maka kebutuhan produk olahan hasil pertanian juga mengalami peningkatan. Selain itu, Dirjen Bina pengolahan dan pemasaran hasil Kementrian Pertanian (2005) juga menyebutkan bahwa dengan melakukan pengolahan, nilai produk akan jauh lebih besar dari hasil produk primernya. Dengan adanya kegiatan pengolahan, juga akan menyerap jumlah tenaga kerja yang besar. Peningkatan kegiatan pengolahan hasil ini juga akan memberi dampak pada peningkatan jumlah permintaan produk bahan baku hasil usahatani (derived demand), baik jumlah, mutu maupun nilainya. Ini juga akan mendorong peningkatan pendapatan ditingkat petani.

Dengan demikian kegiatan Industrialisasi adalah salah satu pendekatan pembangunan pertanian yang dapat menjamin peran pertanian sebagai sumber 
pertumbuhan ekonomi pedesaan yang bisa diandalkan. Hal ini juga memberi pengaruh pada struktur ekonomi pedesaan, yang diharapkan akan lebih dinamis terhadap berbagai perubahan tantangan strategis baik dipasar domestik maupun internasional (Dirjen Pengolahan dan Pemasaran Hasil Pertanian, 2005). Maka kemampuan kewirausahaan pelaku usaha dengan karakteristik yang kuat memiliki peranan penting untuk dapat menghadapinya.

\section{METODE PENELITIAN}

Penelitian ini mengambil Kota Bukittinggi sebagai lokasi. Kota ini dipilih secara sengaja (purposive), karena daerah ini menjadi salah satu daerah kunjungan wisata yang memiliki banyak produk unggulan, salah satunya adalah produk olahan kopi. Dengan menggunakan metode survei, responden diambil secara acak sederhana (Simple Random Sampling) sebanyak 30 orang pelaku agroindustri dari 72 populasi yang ada. Ukuran sampel ini sudah dapat dikatakan layak sebagaimana yang disampaikan oleh Sugiyono, (2004) dalam bukunya Metode Penelitian Bisnis. Data primer yang diperoleh menggunakan kuisioner terbuka melalui wawancara dan pengamatan langsung di lokasi penelitian. Kemudian data sekunder diperoleh dengan studi literatur dan pengambilan data-data yang berasal dari laporan yang terdapat pada Dinas koperasi dan perdagangan Kota Bukittinggi dan sumber lainnya yang dapat dipercaya seperti buku, tulisan ilmiah, media massa baik cetak maupun elektronik/internet.

Variabel yang diamati dalam penelitian ini adalah : Keberanian mengambil risiko, kerja keras dan rasa percaya diri, keuletan, komitmen, wawasan yang luas, kreativitas dan inovasi, serta tanggungjawab pelaku usaha. Pemilihan atribut tersebut diatas sesuai dengan teori yang dikemukan Kashmir, (2010) tentang ciri-ciri wirausaha. Dalam penelitian ini, variabelvariabel tersebut dituangkan kedalam 15 pertanyaan penelitian yang merujuk kepada penelitian yang pernah dilakukan oleh Setyawan \& Masodah (2013), seperti pada Tabel 1 .

Jawaban dari seluruh responden kemudian ditabulasi dan dianalisis secara deskriptif kualitatif. Untuk menetapkan kesimpulan, nilai persentase rata-rata hasil tabulasi kemudian di analisis dengan menggunakan interval data sebagai berikut:
a) Memiliki Jiwa Kewirausahaan Tinggi
: $68-100 \%$
(Kategori 1)
b) Memiliki Jiwa Kewirausahaan Sedang
$: 34-67 \%$
(Kategori 2)
c) Memiliki Jiwa Kewirausahaan Rendah
: $0-33 \%$
(Kategori 3) 
Tabel 1. Daftar Pertanyaan penelitian

\begin{tabular}{|c|c|c|}
\hline \multirow[b]{2}{*}{ NO } & \multirow[b]{2}{*}{ PERTANYAAN } & JAWABAN \\
\hline & & $\begin{array}{lc}\text { YA } & \text { TIDAK } \\
(\%) & (\%)\end{array}$ \\
\hline & Keberanian Mengambil Resiko & \\
\hline 1. & $\begin{array}{l}\text { Jika menghendaki sesuatu, apakah Bapak/Ibu bersedia } \\
\text { menempuh segala resiko untuk mendapatkannya? }\end{array}$ & \\
\hline 2. & $\begin{array}{l}\text { Apakah Bapak/Ibu Dalam melakukan sesuatu selalu } \\
\text { memikirkan tujuan perbuatan itu? }\end{array}$ & \\
\hline 3 & $\begin{array}{l}\text { Apakah Bapak/Ibu senang mengerjakan sesuatu yang } \\
\text { memang cocok untuk diri saja? }\end{array}$ & \\
\hline 4 & Apakah Bapak/Ibu menyukai tantangan?? & \\
\hline & Kerja Keras dan Percaya Diri & \\
\hline 5 & Apakah Bapak/Ibu menyukai kewenangan penuh atas diri? & \\
\hline 6 & $\begin{array}{l}\text { Apakah Bapak/lbu bekerja keras untuk mencapai sasaran } \\
\text { yang diinginkan? }\end{array}$ & \\
\hline 7 & Apakah Bapak/Ibu termasuk orang yang optimis?? & \\
\hline & Keuletan & \\
\hline 8 & $\begin{array}{l}\text { Apakah Bapak/Ibu suka membenamkan diri sepenuhnya } \\
\text { dalam pekerjaan? }\end{array}$ & \\
\hline 9 & $\begin{array}{l}\text { Apakah Bapak/Ibu cukup puas dengan apa yang telah di } \\
\text { lakukan dan hasilkan selama ini? }\end{array}$ & \\
\hline 10 & $\begin{array}{l}\text { Apakah Bapak/Ibu memiliki standar tinggi bagi kualitas } \\
\text { pekerjaan? } \\
\text { Komitmen }\end{array}$ & \\
\hline 11 & $\begin{array}{l}\text { Apakah Bapak/Ibu mengangap perkembangan diri dan } \\
\text { profesi lebih penting daripada rasa tenang, uang dan gengsi? }\end{array}$ & \\
\hline & Wawasan yang Luas & \\
\hline 12 & $\begin{array}{l}\text { Dalam setiap pengambilan keputusan Apakah Bapak/Ibu } \\
\text { biasa menggabungkan daya nalar dan dan intuisi sekaligus?? } \\
\text { Kreatifitas dan Inovasi }\end{array}$ & \\
\hline 13 & Apakah Bapak/Ibu termasuk orang yang kreatif? & \\
\hline 14 & $\begin{array}{l}\text { Apakah Bapak/Ibu suka bereksperimen dengan gagasan } \\
\text { maupun produk-produk Baru?? }\end{array}$ & \\
\hline & Tanggungjawab & \\
\hline 15 & $\begin{array}{l}\text { Apakah Bapak/Ibu merasa sebagai orang yang paling tepat } \\
\text { untuk mengambil keputusan bagi diri sendiri, tidak peduli } \\
\text { jika keputusan itu menentang arus?? }\end{array}$ & \\
\hline
\end{tabular}

Sumber: Kashmir, 2010 ; Setyawan \& Masodah, 2013 


\section{HASIL DAN PEMBAHASAN}

\section{Pola Data Harga Gabah Kualitas Rendah}

Usaha agroindustri kopi di Kota Bukittinggi dijalankan oleh pengusaha yang memiliki usia sudah tidak lagi produktif. Menurut Alma, (2013) "seorang wirausaha sebaiknya adalah seorang yang memiliki kepribadian yang produktif yaitu seorang yang dapat melaksanakan kegiatan yang menimbulkan atau meningkatkan kegunaan (Utility)" dari suatu barang. Hal ini dapat dilihat secara rinci pada tabel 2 dibawah ini:

Tabel. 2. Karakteristik Responden Pelaku Usaha Agroisndustri Kopi di Kota Bukittinggi

\begin{tabular}{|c|c|c|c|}
\hline No & Kategori & Jumlah Orang) & Persentase (\%) \\
\hline \multirow{4}{*}{1} & Umur & & \\
\hline & 15 - 30 Tahun & 0 & 0,00 \\
\hline & 31 - 50 Tahun & 7 & 23,33 \\
\hline & > 50 Tahun & 23 & 76,67 \\
\hline \multirow{5}{*}{2} & Pendidikan & & \\
\hline & SD & 5 & 16,67 \\
\hline & SLTP & 4 & 13,33 \\
\hline & SLTA & 19 & 63,33 \\
\hline & PT & 2 & 6,67 \\
\hline \multirow{3}{*}{3} & Izin Usaha & & \\
\hline & Ada & 13 & 43,33 \\
\hline & Tidak Ada & 17 & 56,67 \\
\hline \multirow{3}{*}{4} & Lama Usaha & & \\
\hline & 0 - 20 Tahun & 10 & 33,33 \\
\hline & >20 Tahun & 20 & 66,67 \\
\hline
\end{tabular}

Sumber : Data Diolah, 2017

Dari tabel diatas dapat terlihat bahwa 23 dari 30 responden pelaku agroindusti kopi di Kota Bukittinggi memiliki usia diatas 50 tahun yaitu sebanyak $76,67 \%$, dengan tingkat pendidikan rata-rata SLTA sebanyak 19 orang $(63,33 \%)$. Sebanyak 17 orang $(56,67 \%)$ pelaku agroindustri tidak memiliki izin usaha, dan hanya 13 orang $(43,33 \%)$ yang memiliki izin usaha. Sebanyak 20 usaha agroindustri kopi sudah dijalankan diatas 20 tahun. Hasil penelitian ini menunjukkan bahwa pelaku agroindustri kopi tersebut rata-rata mampu melaksanakan kegiatan produksi (meningkatkan nilai guna barang) dan bertahan menjalankan usahanya selama 20 tahun keatas, namun sebagain besar mereka masih belum memiliki izin usaha. Brixiova \& Égert, (2017) dalam tulisannya tentang Entrepreneurship, institutions and skills in low-income countries menyatakan bahwa izin usaha diperlukan untuk mengurangi 
dampak rendahnya produktivitas. Oleh karena itu diperlukan regulasi yang kondusif bagi pengusaha untuk dapat memperoleh izin usahanya dengan mudah. Hal ini akan dapat menciptakan lingkungan usaha yang lebih baik dan produktif.

\section{Jiwa Kewirausahaan Pelaku Usaha Kopi di Kota Bukittinggi}

Kashmir, (2010) mendefenisikan Jiwa kewirausahaan adalah kreatif dan inovatif (create new and different) yang merupakan kiat, dasar, sumber daya, proses dan perjuangan untuk menciptakan nilai tambah barang dan jasa dengan keberanian untuk menghadapi risiko. Kemampuan kewirausahaan dimulai dari inisiatif yang akan melahirkan kreativitas (daya cipta) yang kemudian dapat melahirkan inovasi. Dengan mengamati 30 responden dari penelitian diperoleh hasil tabulasi terhadap jiwa kewirausahaan yang dimiliki oleh pelaku agroindustri kopi di Kota Bukittinggi seperti yang tergambar pada Tabel 3.

\section{Keberanian Mengambil Resiko}

Dari tabel 3 dapat dilihat bahwa sebesar $97 \%$ atau sebanyak 29 pelaku usaha agroindustri kopi di Kota Bukittinggi menempuh segala resiko untuk mendapatkan sesuatu yang diinginkan. Berani mengambil resiko adalah jiwa kewirausahaan yang penting yang dimiliki oleh seorang wirausaha. Karena menurut Alma (2013), seorang enterprenuer akan (cenderung) lebih moderat dalam mengambil resiko. Ini menunjukkan bahwa pengusaha agroindustri kopi Rang Bukik Apik berani mengambil resiko usaha yang akan terjadi baik saat ini maupun dimasa yang akan datang.

Selanjutnya, semua pelaku usaha kopi yaitu sebanyak 30 orang merupakan pengusaha yag memiliki jiwa yang selalu memikirkan tujuan dari perbuatan yang dilakukannya, karena tujuan adalah hal penting bagi perkembangan perusahaan. Seorang wirausaha seharusnya adalah seorang yang visioner leader, yaitu seorang yang memimpikan sebuah mimpi besar agar dapat membawa perusahaannya menjadi terus maju dan berkembang dimasa yang akan datang. Menurut Aydin, Araz, \& Ozer-Imer, (2018) tindakan yang dilakukan oleh seorang wirausaha akan memberikan dampak langsung terhadap perubahan sosial dan ekonomi, maka seorang pengusaha yang berpandangan kedepan akan memberikan dampak terhadap perkembangan sosial dan ekonomi masyarakat. 
Tabel 3. Jiwa Kewirausahaan Pelaku Agroindustri Kopi di Kota Bukittingi

\begin{tabular}{|c|c|c|c|}
\hline \multirow{2}{*}{ NO. } & \multirow{2}{*}{ PERTANYAAN } & \multicolumn{2}{|c|}{ JAWABAN } \\
\hline & & \multirow{2}{*}{ YA $(\%)$} & \multirow{2}{*}{ TIDAK $(\%)$} \\
\hline & Keberanian Mengambil Resiko & & \\
\hline 1. & $\begin{array}{l}\text { Jika menghendaki sesuatu, apakah Bapak/Ibu } \\
\text { bersedia menempuh segala resiko untuk } \\
\text { mendapatkannya? }\end{array}$ & 97,00 & 3,00 \\
\hline 2. & $\begin{array}{l}\text { Apakah Bapak/Ibu Dalam melakukan sesuatu selalu } \\
\text { memikirkan tujuan perbuatan itu? }\end{array}$ & 100,00 & 0,00 \\
\hline 3. & $\begin{array}{l}\text { Apakah Bapak/Ibu senang mengerjakan sesuatu yang } \\
\text { memang cocok untuk diri saja? }\end{array}$ & 100,00 & 0,00 \\
\hline \multirow[t]{2}{*}{4.} & Apakah Bapak/Ibu menyukai tantangan? & 80,00 & 20,00 \\
\hline & Kerja Keras dan Percaya Diri & & \\
\hline 5. & $\begin{array}{l}\text { Apakah Bapak/Ibu menyukai kewenangan penuh atas } \\
\text { diri? }\end{array}$ & 83,30 & 16,70 \\
\hline 6 & $\begin{array}{l}\text { Apakah Bapak/Ibu bekerja keras untuk mencapai } \\
\text { sasaran yang diinginkan? }\end{array}$ & 97,00 & 3,00 \\
\hline \multirow[t]{2}{*}{7} & Apakah Bapak/Ibu termasuk orang yang optimis?? & 90,00 & 10,00 \\
\hline & Keuletan & & \\
\hline 8 & $\begin{array}{l}\text { Apakah Bapak/Ibu suka } \\
\text { sepenuhnya dalam pekerjaan? }\end{array}$ & 83,00 & 17,00 \\
\hline 9 & $\begin{array}{l}\text { Apakah Bapak/Ibu cukup puas dengan apa yang telah } \\
\text { di lakukan dan hasilkan selama ini? }\end{array}$ & 87,00 & 13,00 \\
\hline \multirow[t]{2}{*}{10.} & $\begin{array}{l}\text { Apakah Bapak/Ibu memiliki standar tinggi bagi } \\
\text { kualitas pekerjaan saya? }\end{array}$ & 90,00 & 10,00 \\
\hline & Komitmen & & \\
\hline \multirow[t]{2}{*}{11.} & $\begin{array}{l}\text { Apakah Bapak/Ibu mengangap perkembangan diri } \\
\text { dan profesi lebih penting daripada rasa tenang, uang } \\
\text { dan gengsi? }\end{array}$ & 80,00 & 20,00 \\
\hline & Wawasan yang Luas & & \\
\hline 12. & $\begin{array}{l}\text { Dalam setiap pengambilan keputusan Apakah } \\
\text { Bapak/Ibu biasa menggabungkan daya nalar dan dan } \\
\text { intuisi sekaligus?? } \\
\text { Kretivitas dan Inovasi }\end{array}$ & 73,00 & 27,00 \\
\hline 13. & Apakah Bapak/Ibu termasuk orang yang kreatif? & 60,00 & 40,00 \\
\hline \multirow[t]{2}{*}{14.} & $\begin{array}{l}\text { Apakah Bapak/Ibu suka bereksperimen dengan } \\
\text { gagasan maupun produk-produk Baru?? }\end{array}$ & 50,00 & 50,00 \\
\hline & Tanggungjawab & & \\
\hline \multirow[t]{3}{*}{15.} & $\begin{array}{l}\text { Apakah Bapak/Ibu merasa sebagai orang yang paling } \\
\text { tepat untuk mengambil keputusan bagi diri sendiri, } \\
\text { tidak peduli jika keputusan itu menentang arus?? }\end{array}$ & 67,00 & 33,00 \\
\hline & Total & $1.237,30$ & 262,70 \\
\hline & Rata-Rata & 82,49 & 17,51 \\
\hline
\end{tabular}

Sumber : Data Diolah , 2017 
Kemudian, hasil penelitian ini juga menunjukkan bahwa semua pelaku usaha kopi di Kota Bukittinggi termasuk kedalam katergori pengusaha yng senang mengerjakan sesuatu yang memang cocok untuk dirinya. Dalam karakteristik seorang wirausaha ini disebut juga dengan rasa percaya diri. Selain percaya diri, sebanyak $80 \%$ pelaku agroindustri kopi di Kota Bukittinggi juga menyukai tantangan.

\section{Kerja Keras, Percaya Diri dan Ulet}

Berikutnya, kewenangan penuh atas diri sendiri merupakan salah satu jiwa kewirausahaan yang dikemukakan oleh Joseph Schmidt yang harus dimiliki oleh seorang wirausaha. Berdasarkan hasil penelitian kewenangan penuh atas diri sendiri ini dimiliki sebanyak $83 \%$ dari total pelaku usaha kopi di Kota Bukittinggi. Sebanyak 90\% pelaku usaha kopi di Kota Bukittinggi ini juga termasuk orang yang optimis dalam melakukan sesuatu. Mereka juga merupakan orang yang suka membenamkan diri sepenuhnya terhadap pekerjaan yaitu sebanyak $83,3 \%$. Kemudian $87 \%$ atau 26 orang pelaku usaha kopi selalu puas atas apa yang telah dilakukan dan dihasilkan selama ini. Hal ini termasuk kedalam kategori berorientasi pada tugas dan hasil. Menurut Alma (2013), orang seperti ini adalah orang yang mendahulukan prestasi dibandingkan dengan prestise. Salah satunya dengan mengedepankan standar yang tinggi dan kualitas yang baik dalam menghasilkan suatu produk, hal ini dikarenakan kualitas dapat mempertinggi harga jual dari suatu produk. Sebanyak $90 \%$ responden mementingkan kualitas produk kopi yang mereka hasilkan. Ini adalah ciri keuletan dari seorang wirausaha.

\section{Komitmen}

Sementara itu sebanyak $80 \%$ pelaku usaha kopi di Kota Bukittinggi menganggap perkembangan diri dan profesi lebih penting dari pada rasa tenang, uang dan gengsi. Karena setiap perubahan oleh seorang wirausaha dianggap mengandung peluang yang merupakan masukan dan rujukan terhadap pengambilan keputusan (Alma, 2013). Bekerja keras dalam mencapai sasaran yang diinginkan merupakan salah satu jiwa kewirausaahan yang dimiliki oleh seorang wirausaha. Sebagian besar atau sebanyak $97 \%$ pelaku usaha di Kota Bukittinggi memiliki jiwa bekerja keras untuk mencapai sasaran yang diinginkan. Demi hasil yang maksimal maka Alma, (2013) mengatakan bahwa seorang wirausaha akan melakukan kegiatannya dengan smart (cerdas, pintar, bijak) karena seorang wirausaha adalah seseorang yang di dominasi oleh otak kanan yang mendorong bekerjanya intuisi, namun hanya sebesar $73 \%$ pelaku 
usaha kopi di Kota Bukittinggi yang bisa menggabungkan daya nalar dan intuisi sekaligus dalam setiap pengambilan keputusan.

\section{Kretifitas, Inovasi dan Tanggungjawab}

Untuk menciptakan nilai tambah yang lebih tinggi dari suatu produk, penting untuk melakukan eksperimen dan gagasan baru untuk menciptakan suatu produk bernilai tambah tersebut. Namun, hanya sebanyak 50\% saja pelaku usaha kopi di Kota Bukittinggi yang mementingkan eksperimen dan gagasan baru.

Selanjutnya, sebesar $60 \%$ pelaku usaha kopi di Kota Bukittinggi memiliki kreativitas dalam menghasilkan produk. Ini merupakan modal utama dari seorang wirausaha. Karena jika, seorang wirausaha yang memiliki kreatifitas akan selalu menghadapi tantangan, mereka akan merubah tantangan tersebut menjadi peluang. Kreativitas dari wirausaha juga akan memberikan dampak pada perkembangan sosial dan ekonomi masyarakat, mendorong munculnya tekhnologi baru yang dapat meningkatkan jumlah produksi sehingga pada akhirnya akan mendorong pertumbuhan ekonomi negara (Aydin et al., 2018). Hal ini juga tergambarkan dengan sebanyak $63 \%$ pelaku usaha kopi di Kota Bukittinggi mengganggap diri sendiri adalah yang paling tepat dalam mengambil keputusan dan tidak peduli jika keputusan itu menentang arus. Hal ini sejalan dengan apa yang dinyatakan oleh Palmer bahwa faktor individu pengusaha yang kuat sangat berperan penting dalam proses pengambilan keputusan guna mencapai tujuan perusahaan untuk lebih maju (Palmer, Niemand, Stöckmann, Kraus, \& Kailer, 2019), dan berani mengambil resiko yang mungkin akan dihadapi dengan adanya keputusan tersebut. Ini menujukkan rasa tanggungjawab yang tinggi terhadap perkembangan usaha.

Dari 15 indikator yang dinilai, hasil penjumlahan rata-rata untuk keseluruhan indikator adalah $82,49 \%$. Angka persentase ini menunjukkan secara keseluruhan pelaku agroindustri kopi di Kota Bukittinggi memiliki jiwa kewirausahaan yang tinggi. Pelaku agroindustri kopi di Kota Bukittinggi adalah orang yang bersedia menempuh segala resiko, suka bekerja keras dan percaya diri, ulet, berkomitmen, memiliki wawasan yang luas, kreatif dan inovatif serta bertanggungjawab. Dengan jiwa kewirausahaan yang dimiliki, digabungkan dengan pengalaman usaha yang sudah lama, diharapkan dapat membuat pelaku usaha agroindustri kopi di Kota Bukittinggi mampu menghadapi perkembangan persaingan global. Namun, dari pada itu pelaku agroindustri kopi diharapkan juga untuk dapat meningkatkan daya kreatifitasnya dan berani mengambil keputusan untuk mengikuti arah perkembangan industri ke arah digitalisasi proses produksi dan pemasaran 
produk agar dapat bersaing secara global dalam era revolusi industri 4.0. Karena kelincahan industri merupakan hal penting agar tetap bertahan dalam persaingan agar usaha dapat terus berlanjut. Keberlanjutan usaha secara ekonomi dientukan oleh kemampuan pengusaha untuk menghadapi segala tantangan yang ada. Model bisnis (Brehmer, Podoynitsyna, \& Langerak, 2018; Rauter, Jonker, \& Baumgartner, 2017) juga akan dapat mempengaruhi keberlanjutan usaha, seorang pengusaha yang handal akan dapat menggerakkan segala sumberdaya yang dimiliki untuk dapat mendatangkan keuntungan bagi perusahaan dengan model bisnis yang dipilihnya.

Kemudian keberlanjutan usaha juga akan dipengaruhi oleh persepsi konsumen terhadap produk (Van Loo et al., 2015). Produk pangan akan sangat sensitif terhadap isu keamanan pangan, maka daya kreasi dan tampilan produk serta label keamanan pangan akan sangat mempengaruhi keberlanjutan usaha secara sosial dan lingkungan. Untuk agroindustri kopi sendiri, keamanan pangan seharusnya diperhatikan mulai dari hulu (bahan baku) yaitu biji kopi yang diproduksi oleh petani yang memiliki sertifikat (Giuliani, Ciravegna, Vezzulli, \& Kilian, 2017) hingga proses produksi dan distribusi produk yang bersih dan sehat, sehingga produk aman dikonsumsi oleh konsumen.

\section{SIMPULAN DAN SARAN}

\section{Simpulan}

Berdasarkan hasil penilaian pada masing-masing indikator yang mengukur jiwa kewirausahaan pelaku usaha kopi di kota Bukittinggi didapatkan bahwa pelaku usaha memiliki jiwa kewirausahaan yang tinggi. Hal ini dilihat dari nilai total indikator jiwa kewirausahaan sebesar 82,49\%. Dengan demikian mereka adalah orang yang bersedia menempuh segala resiko, suka bekerja keras dan percaya diri, ulet, berkomitmen, memiliki wawasan yang luas, kreatif dan inovatif serta bertanggungjawab.

\section{Saran}

Setiap pelaku agroindustri kopi di Kota Bukittinggi yang memiliki jiwa kewirausahaan dapat terus mengembangkan diri melalui inovasi produk dan meningkatkan penciptaan nilai tambah dalam menghadapi tantangan globalisasi yang menuntut keterbukaan dan berorientasi pada digitalisasi proses produksi dan pemasaran produk, agar tidak kalah pada persaingan global era revolusi industri 4.0 dan berakhir hanya sebagai "pedagang pinggiran". 


\section{DAFTAR PUSTAKA}

Alma, B. 2013. Kewirausahaan Edisi Revisi. Bandung: Alfabeta.

Aydin, D. G., Araz, B., \& Ozer-Imer, I. 2018. Adventurous and charismatic spirits: Entrepreneurs of Veblen and Schumpeter. Economics Letters, 169, 24-26. https://doi.org/10.1016/j.econlet.2018.05.004

Badan Pusat Statistik. 2015. Peningkatan Kinerja Pertanian Menuju Kedaulatan Pangan. Jakarta: BPS.

Badan Pusat Statistik Sumatera Barat. 2018. Sumatera Barat Dalam Angka. Padang: BPS.

Brehmer, M., Podoynitsyna, K., \& Langerak, F. 2018. Sustainable business models as boundary-spanning systems of value transfers. Journal of Cleaner Production, 172, 4514-4531. https://doi.org/10.1016/j.jclep ro.2017.11.083

Brixiova, Z., \& Égert, B. 2017. Entrepreneurship, institutions and skills in lowincome countries. Economic Modelling, 67(June 2016), 381-391. https://doi.org/10.1016/j.econmod.2017.02.020

Direktorat Jenderal Perkebunan. 2017. Kopi. 83. Retrieved from http://ditjenbun.pertanian.go.id

Giuliani, E., Ciravegna, L., Vezzulli, A., \& Kilian, B. 2017. Decoupling Standards from Practice: The Impact of In-House Certifications on Coffee Farms' Environmental and Social Conduct. World Development, 96, 294-314. https://doi.org/10.1016/j.worlddev.2017.03.013

Hassim, A. 2016. Revolusi Industri 4.0. Investor Daily Indonesia, -.

Kashmir. 2010. Kewirausahaan. Jakarta: Raja Grafindo Persada.

Nazir, M. 2009. Metode Penelitian Cet. Ke-5. Jakarta: Ghalia Indonesia.

Nunes, L. B. 2016. Schumpeter's entrepreneurs in the 20th century: The Tucker automobile. Technological Forecasting and Social Change, 102, 14-20. https://doi.org/10.1016/j.techfore.2015.02.021

Palmer, C., Niemand, T., Stöckmann, C., Kraus, S., \& Kailer, N. 2019. The interplay of entrepreneurial orientation and psychological traits in explaining firm performance. Journal of Business Research, 94(November 2017), 183-194. https:// doi.org/10.1016/j.jbusres.2017.10.005

Rauter, R., Jonker, J., \& Baumgartner, R. J. 2017. Going one's own way: drivers in developing business models for sustainability. Journal of Cleaner Production, 140, 144-154. https://doi.org/10.1016/j.jclepro.2015.04.104

Setyawan, A. B., \& Masodah. 2013. Analisis Kepemilikan Jiwa Wirausaha Pada Pelaku Usaha Kecil dan Menengah di Kota Depok. Proceeding PESAT (Psikologi, Ekonomi, Sastra, Arsitektur \& Teknik Sipil), 5, 8-9.

Soedjais, Z. 2003. Good Governance, Daya Saing dan Investasi Global. Jurnal Ilmu Sosial dan Politik, 6(3):209-328

Sugiyono. 2004. Metode Penelitian Bisnis. Bandung: Alphabeta. 
Tuluce, N. S. 2015. Term of Strategic Entrepreneurship and Schumpeter's Creative Destruction Theory. Procedia - 207 ( 2015 )(Social and Behavioral Sciences), $720-728$.

Van Loo, E. J., Caputo, V., Nayga, R. M., Seo, H. S., Zhang, B., \& Verbeke, W. 2015. Sustainability labels on coffee: Consumer preferences, willingness-to-pay and visual attention to attributes. Ecological Economics,118,215-225. https://doi.org/10.1016/j.ecolecon.2015.07.011 